\title{
Peranan Persekitaran terhadap Tuntutan Hak Asasi Manusia: Cabaran bagi Umat Islam
}

\author{
The Role of the Environment in Human Rights: \\ The Challenges Faced by the Muslim Ummah
}

ZUL`AZMI YAAKOB* \& ZAILAN MORIS ${ }^{1}$

\begin{abstract}
The term 'environment' refers to both the natural world as well as the surroundings of and influences on a particular thing. The environment plays a major role and influence on human beings and their lives. This article discusses the influential role the environment plays in relation to human rights. Today, human rights is a global issue and the rights that are advocated range from the basic human needs of food and shelter to the right of freedom of speech to the more religiously contentious gay rights. This paper contends that the issue of human rights is closely connected to the environment or the social conditions of a particular community; specifically the values and principles which dominate and determine the worldview of that community or society. In the context of our global society, the issue of deciding the content and nature of human rights is extremely challenging, especially to religious societies and communities, since religious principles and values are no longer a dominant factor in determining what is right or wrong, good or bad. This is the situation faced by the Muslim ummah. Many of the rights advocated by the modern West which it considers to be fundamental, universal and human are contrary to Islamic principles and values. For example, the right of freedom of speech to insult and mock the sacred tenets in religious teachings, the right to gay marriages which run contrary to natural laws, and the right to exploit natural resources for economic development without regard to the rights of other creatures which also inhabit this world. Thus, the Muslim ummah is in a dilemma as to whether to adapt itself to the modern and secular global environment or change its environment to advocate its Islamic worldview and understanding of human nature, rights, responsibilities and freedom.
\end{abstract}

Keywords: environment, freedom, human rights, Islam, worldview

Sarjana Barat Kristian seperti Chuck Mcllhenny, Donna Mcllhenny dan Frank York (1993: 11-14 \& 80-86) dalam bukunya When the Wicked Seize a City menjelaskan, ruang 'kebebasan' yang diamalkan di Barat selama ini semakin banyak memberi kesan keburukan berbanding kebaikan terhadap masyarakatnya. Bermula dengan 'kebebasan' dalam bersuara, mereka kini begitu berani menuntut pelbagai 'kebebasan' lain hatta secara kekerasan dan keganasan. 'Kebebasan' dianggap sebagai penyelesaian untuk mendapatkan 'kesamarataan' hak bagi setiap manusia. Namun, kepelbagaian tuntutan atas nama 'kebebasan' kebelakangan ini amat jelas bertentangan dengan peraturan agama Kristian yang dianuti. Banyak kejayaan tuntutan mereka diperolehi

\footnotetext{
${ }^{1}$ Zul azmi Yaakob*(Corresponding author), M.A., Lecturer at Dept. of Theology and Philosophy, Faculty of Islamic Studies, Universiti Kebangsaan Malaysia, 43600 BANGI, Selangor, Malaysia, email: zulazmi@ukm.edu.my; Zailan Moris, Ph.D., Professor at the School of Humanities, Universiti Sains Malaysia, 11800 USM, Penang, Malaysia, email: zailan@usm.my.
} 
melalui pengaruh atau kuasa pemerintahan, pentadbiran, politik dan sokongan orang ramai. Sebagai contoh, tuntutan untuk mengamalkan budaya seks bebas iaitu tanpa perlu melalui ikatan perkahwinan, telah sebati dikaitkan dengan amalan masyarakat Barat moden. Ia telah menyumbang kepada peningkatan kes kelahiran anak luar nikah. Tanpa berselindung lagi, masyarakat Barat pada hari ini turut disebatikan dengan cara hidup yang mengamalkan budaya hubungan songsang atau perkahwinan songsang iaitu perkahwinan sesama jenis seperti golongan gay dan lesbian. Tidak dinafikan lagi, semua ini adalah kesan 'kebebasan' yang diperjuangkan di Barat sekian lama, sehingga meminggirkan nilai agama. Mereka sebaliknya sentiasa cuba memenuhi segala tuntutan hawa nafsu dan logik akal sekular atas nama Human Rights (Hak Asasi Manusia).

Human Rights yang difahami sebagai Hak Asasi Manusia (HAM) merupakan satu aliran yang mempunyai keistimewaan dan pengaruhnya yang besar. Ia sering diimejkan bersifat 'neutral' dan 'adil' bagi semua pihak, dan ini menyebabkan jenama HAM semakin popular kerana sifat sedemikian begitu selesa diperjuangkan oleh mana-mana golongan majoriti dan minoriti termasuklah di kalangan kapitalis, sosialis, modenis dan bagi mereka yang mendakwa dirinya sering menjadi mangsa penindasan. Ada yang meletakkan taraf HAM sebagai satu 'agama' baru kerana tuntutan-tuntutan yang dikemukakan sentiasa mendapat sokongan kuat masyarakat sekelilingnya seperti kalangan sarjana, ahli politik, golongan agama, pemerintah, badan bukan kerajaaan (NGO) dan orang ramai. Slogan-slogan seperti mengutamakan 'kebebasan', memperjuangkan 'kesamarataan' dan menghapuskan 'diskriminasi', sentiasa diimejkan dalam bentuk 'nilai' positif yang mutlak dan relevan ke atas apa jua aspek yang ingin dituntut. Ia termasuklah dalam sektor ekonomi, perundangan, pentadbiran, pemerintahan, pendidikan, agama dan perkahwinan. Slogan-slogan tersebut telah diglobalkan penggunaannya oleh para pendukung HAM, bahkan sehingga kini ia juga telah berjaya meresapi pemikiran (ideologi) masyarakat Islam. 'Persekitaran' sedemikian telah membawa kepada perkembangan falsafah sekularisme, pluralisme dan liberalisme.

Sikap masyarakat Barat yang begitu melebih-lebihkan tuntutan hawa nafsu dan logik akal modenisme berbanding tuntutan agama, dilihat ketara semenjak zaman moden khususnya setelah kemasukan era Renaisans. Ketika itu, dikatakan ramai ahli falsafah dan pemikir di dalam penulisan masing-masing sering mengagung-agungkan kedudukan manusia. Mereka meletakkan peranan akal manusia mengatasi peranan agama. Tuntutan-tuntutan yang dipaparkan dalam penulisan mereka hanyalah berlandaskan etika ciptaan manusia sematamata, bukannya etika yang dibawakan oleh agama (Kristeller 1972: 18-21). Etika ciptaan manusia yang memutlakkan penggunaan akal modenisme telah membentuk falsafah yang mendewakan manusia sedangkan etika bawaan agama melahirkan falsafah ketuhanan yang sentiasa mengikat spiritual manusia kepada Tuhan (Lonergan 1973: 1-4). Sikap keterlaluan mengagungkan akal modenisme dan keupayaan manusia, telah menyebabkan peranan agama semakin dipinggirkan. Di Barat, kedudukan agama kini tidak lagi menjadi paksi ataupun kayu ukur dalam menentukan baik dan buruk perbuatan manusia. Akibatnya, mereka semakin berani melakukan kegiatan ataupun budaya yang menyalahi etika yang dituntut oleh agama. Ia merupakan kesan daripada 'persekitaran' yang tidak terdedah dengan nilai agama iaitu suasana kejahilan. Sebab itulah masyarakat Barat seringkali dilabelkan sebagai golongan yang mengamalkan budaya memonopoli dan mengeksploitasi dalam ekonomi, budaya 'bebas' dalam pergaulan dan budaya hedonisme dalam mencapai kebahagiaan. Label sedemikian juga boleh berlaku dalam mana-mana negara sekalipun termasuklah dunia Islam, apabila sesuatu 'persekitaran' itu telah meletakkan keagungan manusia mengatasi keagungan Tuhan. 


\section{Hak Asasi Manusia dari Perspektif Islam}

Hak Asasi Manusia ciptaan Barat moden begitu ketara nilai sekularnya. Dalam Islam, perkara yang dikaitkan dengan Hak Asasi Manusia sebenarnya terangkum pada prinsip asas Maqasid alSyari'ah iaitu memelihara agama, nyawa, akal, keturunan dan harta. Pemeliharaan tersebut merupakan asas kepada keperluan manusia yang tetap terikat dengan nilai agama dalam menjalankan segala aktiviti di muka bumi (Nasharudin Mat Isa 2014: 14-15). Dengan kata lain, umat Islam tidak diberikan 'kebebasan' mutlak untuk melakukan apa sahaja kerana mereka adalah golongan beragama iaitu makhluk yang sentiasa terikat dengan Penciptanya, Allah (s.w.t.) Mereka wajib pada asasnya untuk melakukan apa sahaja cara demi memelihara agama, nyawa, akal, keturunan dan harta masing-masing, tetapi dengan syarat semua perbuatan pemeliharaan tersebut mestilah tertakluk pada peraturan Allah (s.w.t.) Sebagai contoh, umat Islam tidak boleh mengamalkan riba dalam urusan pinjaman kewangan dan perniagaan. Mereka juga tidak dibenarkan memonopoli, mendominasi dan mengeksploitasi sumber alam walaupun matlamat mereka hanyalah untuk mencari rezeki (memelihara harta). Atas nama Hak Asasi Manusia (HAM), sikap para pendukung HAM mengetengahkan 'kebebasan' manusia secara sekular dan melampau, telah menjadi satu ancaman terhadap golongan tradisi beragama. Mereka tidak menerapkan adab keTimuran dan nilai agama, sebaliknya mendakwa semua itu hanyalah alat untuk mengongkong segala 'kebebasan' aktiviti harian manusia. 'Kebebasan' secara mutlak untuk manusia menjadi keutamaan berbanding 'kebaikan' sejagat yang dibawakan oleh agama dan peraturan-peraturannya.

Beberapa tuntutan HAM kebelakangan ini didapati semakin menonjol diperjuangkan sama ada di kalangan masyarakat Barat mahupun Islam. Ia menjadi satu cabaran besar bagi umat manusia kerana banyak tuntutan mereka diberikan keutamaan mengatasi had dan peraturan disediakan oleh agama. 'Kebebasan' pada setiap manusia telah difahami dalam konteks terpisah daripada ikatan Tuhan. Kesannya turut menghasilkan pemahaman 'kebebasan' untuk menjadi individu yang beragama ataupun yang menolak agama (ateis). Kesan-kesan yang lain pula termasuklah 'kebebasan' memonopoli ekonomi sehingga mewujudkan penindasan, 'kebebasan' dalam menggunakan sumber alam sehingga mewujudkan krisis alam sekitar dan 'kebebasan' bagi golongan wanita yang telah berkeluarga untuk menjadi ketua keluarga atas nama 'kesamarataan' dan menghapuskan 'diskriminasi'. Keadaan-keadaan sedemikian menggambarkan betapa penglobalan maksud 'Hak Asasi Manusia' dalam acuan Barat sekular, kini telah menjadi dominan, memanipulasi, mengeksploitasi dan mengatasi 'Hak' bawaan agama.

Dalam Islam, istilah 'Hak' atau dalam bahasa Arabnya al-Haqq, secara dasar utamanya membawa maksud 'Kebenaran' iaitu Allah s.w.t sebagai Kebenaran Maha Agung (Ibn Manzur 1996: 255-256). Justeru, kedudukan 'Hak' adalah lebih tinggi berbanding 'Hak Asasi Manusia', malah 'Hak Asasi Manusia' sepatutnya tertakluk di bawah peraturan 'Hak'. Akan tetapi, realiti pada hari ini banyak menunjukkan tuntutan 'Hak' yang semakin dipinggirkan umat Islam berbanding 'Hak Asasi Manusia' sekular, malah menjadi agenda utama dalam 'pembangunan' dan 'kemajuan'. 'Persekitaran' sedemikian juga seakan 'diterima baik' oleh segelintir pemikir Islam dan golongan ulama, sekaligus menunjukkan bahawa telah wujud cabaran besar di kalangan umat Islam dalam berhadapan implikasi daripada falsafah Barat moden.

\section{Peranan Persekitaran terhadap Tuntutan Masyarakat}

Tuntutan-tuntutan melampau umat manusia masa kini yang semakin meminggirkan ajaran agama tidak berlaku secara kebetulan. Ia berhubung kait dengan pengaruh keadaan 'persekitaran' yang juga disebut sebagai 'alam sekitar' ataupun 'alam sekeliling'. 'Persekitaran' bagi sesuatu tempat yang diduduki tidak terhad hanya kepada bentuk material bangunan, kewujudan pokok dan hidupan lain yang mengeliling mereka, tetapi turut merangkumi bentuk 
spiritual, khususnya unsur keagamaan yang terdapat di sekitarnya. Ia juga meliputi tahap perkembangan dan penghayatan keagamaan yang berjaya ditonjolkan dalam sesuatu kawasan atau masa. Antaranya ialah tahap penguasaan ilmu agama, penonjolan banyak penulisan berunsurkan keagamaan ataupun falsafah ketuhanan, terdedahnya dengan suasana amalan masyarakat yang membudayakan kehidupan beragama dalam semua aktiviti yang dijalankan (masyarakat tradisi beragama). Dalam masa yang sama, unsur sekular dalam bidang ilmu, penulisan, pemikiran ataupun falsafah serta budaya amalan yang bertentangan dengan nilai agama tidak dibenarkan berlaku dalam 'persekitaran' tersebut. Ia bertujuan untuk mengelakkan pengaruhnya daripada terus berkembang.

'Persekitaran' yang bermaksud 'kawasan di sekeliling sesuatu tempat' atau 'kawasan sekitar' (Noresah Baharom 2007: 797), juga boleh difahami sebagai 'alam sekeliling' ataupun 'alam sekitar'. Keadaan pada 'persekitaran' mempunyai banyak kemungkinan dalam mempengaruhi tuntutan (keinginan atau kehendak) mahupun tingkah laku manusia yang mendiaminya. Berdasarkan pengalaman sejarawan Islam seperti Ibn Khaldun (m. 1406M), beliau mengeluarkan teori bahawa 'persekitaran' berpotensi mempengaruhi tuntutan dan tingkah laku manusia yang mendiaminya termasuklah dari segi kelangsungan hidup dan aktiviti berekonomi. Misalnya, apabila sesuatu kawasan itu begitu banyak sumber makanan dan mudah diperolehi, ia secara tidak langsung mendorong masyarakat di kawasan tersebut menjadikannya sebagai makanan asasi (makanan ruji). Mereka akan cuba membiasakan diri dengan jenis makanan tersebut agar bersesuaian dengan seleranya. Jika gandum begitu banyak dan mudah diperolehi di situ, maka gandum akan menjadi makanan asasinya (Ibn Khaldun 1981: 112-113). 'Persekitaran' juga mempengaruhi hidupan lain seperti haiwan dan serangga. Ini ada dijelaskan oleh Ibn Khaldun:

\begin{abstract}
Hal ini dapat dibandingkan dengan perbezaan yang wujud di sesuatu atau di kota yang sama berkenaan dengan kandang-kandang binatang yang dijauhi atau sering didatangi. Kawasan dan perkarangan kediaman orang-orang kota yang makmur dan kaya-raya, yang duduk di atas kerusi meja yang baik dan di mana biji-bijian dan lebihan roti didapati bertaburan di merata tempat, maka rumah itu akan sering dikerumuni oleh gerombolan semut dan serangga. Terdapat banyak tikus di ruang-ruang bawah tanah dan kucing-kucing bagaikan tidak dapat duduk diam. Sekawan burung berterbangan di atasnya, dan akhirnya terbang semula, setelah memenuhi paruhnya dengan makanan dan minuman. Sedangkan di halaman rumah orang-orang serba kekurangan dan miskin, tidak ada serangga pun yang merayap dan tidak ada seekor burung pun yang terbang ke atasnya, dan tidak ada tikus atau kucing sibuk ke sana ke mari di pojok-pojok rumah. . . Segala apa yang menjadi rahsia Allah s.w.t haruslah diteliti secara mendalam. Seseorang boleh membandingkan antara kerumunan manusia dengan kerumunan sekawan binatang, serta cebisan makanan di meja dengan lebihan makanan dan kemewahan, serta pembaziran yang dilakukan oleh mereka yang memilikinya, sebab sebagai lazimnya mereka berupaya melakukan tanpa adanya itu sebab mereka memiliki semuanya itu (Ibn Khaldun 2000: 413-414).
\end{abstract}

Apabila masyarakat begitu mudah memperolehi sumber alam yang begitu banyak di persekitarannya, maka ia telah mempengaruhi mereka untuk hidup secara bermewahmewahan, tanpa memikirkan kesan kehabisan sumber alam dalam jangka masa yang panjang. Mereka tidak memikirkan bagaimana untuk hidup berjimat cermat dalam menggunakan sumber alam demi untuk generasi akan datang. Huraian di atas juga menunjukkan, bagaimana 'persekitaran' material seperti keadaan makanan bertaburan yang dibazirkan, boleh mempengaruhi hidupan lain untuk mengerumuninya. Meskipun begitu, melihat kepada huraian tersebut, didapati manusia yang merupakan salah satu ciptaan (makhluk), turut berperanan menjadi faktor kepada pembentukan 'persekitaran', sekaligus boleh mempengaruhi manusia lain dan makhluk selainnya termasuklah haiwan dan tumbuh-tumbuhan. Biarpun lebihan makanan yang bertaburan telah mempengaruhi kedatangan haiwan dan serangga, tetapi 
budaya pembaziran itu adalah bermula daripada sikap manusia sendiri. Betapa mudahnya untuk mendapatkan makanan, mungkin telah mempengaruhi sikap mereka untuk melakukan pembaziran. Akan tetapi, sikap membazir itu boleh ditangani sekiranya mereka yang mendiaminya mempunyai ilmu dan penghayatan terhadap agama anutannya. Ini kerana, jika seseorang itu memiliki ilmu dan penghayatan terhadap agama, pasti dirinya tidak akan mengamalkan budaya pembaziran makanan kerana amalan tersebut adalah dilarang oleh Tuhan sebagaimana terkandung dalam ajaran agama. Kejahilan tentang larangan membazirkan makanan bagi masyarakat yang mendiami kawasan tersebut merupakan salah satu faktor 'persekitaran'. Ini menunjukkan masyarakat tersebut dikelilingi dengan persekitaran yang penuh kejahilan dan kurangnya penghayatan tentang ilmu agama dalam penggunaan sumber alam dan adab pemakanan. Justeru, manusia dilihat memainkan dua peranan penting iaitu bertindak sebagai agen yang boleh dipengaruhi oleh 'persekitaran', juga sebagai agen yang boleh mempengaruhi 'persekitaran'. Manusia boleh mempengaruhi 'persekitarannya' sehingga boleh menghasilkan tindak balas sama ada baik atau tidak baik.

'Keinginan', 'kemahuan' atau 'kehendak', juga dimaksudkan sebagai 'tuntutan'. Ia mempunyai kesan baik dan buruknya. Namun, jika 'tuntutan' yang diperjuangkan telah melangkaui 'keperluan' seadanya sebagaimana yang telah dihadkan oleh agama, maka kesan buruknya akan lebih ketara. Semua ini bertitik tolak pada 'nilai' yang digunakan sama ada berpaksikan kemanusiaan modenisme ataupun ketuhanan (agama). Dalam konteks masa kini, istilah 'kemanusiaan' telah diglobalkan maksudnya sebagai 'kemanusiaan' semata-mata tanpa melibatkan persoalan agama, yang membawa pemahaman moden sekular. Dari perspektif agama, tuntutan yang memberikan kesan yang baik adalah tuntutan manusia yang sentiasa dinaungi oleh peraturan agama. Bagi tuntutan yang memberikan kesan tidak baik, ia adalah tuntutan manusia yang terlalu mengagungkan 'kebebasan' mereka sehingga melampaui peraturan agama. Mereka membawa 'kebebasan' yang lebih banyak bersandarkan tuntutan hawa nafsu semata-mata, atau akal rasional modenisme sahaja, atau kedua-duanya, yang berpunca daripada kejahilan dan kurangnya penghayatan ilmu agama.

Ahli falsafah Barat moden seperti Ludwig Feuerbach (m. 1872M) menjelaskan, manusia berhak menuntut dan melakukan apa sahaja ke atas alam ini walaupun melanggari peraturan agama. Beliau berpendapat sedemikian kerana pemahamannya adalah manusia itu telah diberikan 'kebebasan', bukannya kongkongan mahupun sekatan (Feuerbach 1957: 185-188). Ramai yang telah memahami konsep 'kebebasan' dalam bentuk acuan sekular apabila cuba dikaitkan dengan tuntutan-tuntutan pada aktiviti manusia. Sarjana Melayu seperti Za'ba (m. 1973M) pernah menjelaskan, 'kebebasan' dimaksudkan sebagai keinginan dan keupayaan manusia yang boleh melakukan pelbagai ikhtiar, tetapi ia tetap terikat dengan nilai agama kerana tujuan hidup manusia adalah untuk mencapai kebaikan di dunia dan akhirat. Malah, Za'ba sendiri menegaskan, segala 'kebebasan' pada keinginan dan ikhtiar manusia yang berjaya menghasilkan kesan kebaikan di dunia dan akhirat, sebenarnya berpunca daripada manusia yang sentiasa membuat pilihan secara bijaksana iaitu kebijaksanaan dalam menjaga hubungan baiknya dengan Allah s.w.t (Za'ba 1980: 80-84). Dalam apa jua sekalipun 'kebebasan' yang dituntut oleh manusia, ia wajib terikat dengan peraturan agama. Ini termasuklah sentiasa menjaga hubungan baiknya dengan Allah s.w.t, hubungan sesama manusia dan hubungan terhadap alam. Oleh demikian, manusia dilihat boleh mengubah 'persekitaran' sama ada untuk menghasilkan kebaikan mahupun keburukan yang tertakluk kepada kebijaksanaan dalam membuat pilihan. Manusia hanya mampu mencipta 'alam sekeliling', 'alam sekitar' ataupun 'persekitaran' sahaja, tetapi tidak boleh mencipta 'alam'. 'Alam' yang luas ini (meliputi manusia, haiwan, tumbuhan dan sebagainya) adalah ciptaan Allah s.w.t yang disediakan bersama peraturan-peraturan-Nya, sekaligus perlu ditaati oleh semua makhluk-Nya. 


\section{Kepentingan Persekitaran Islamiah}

Nilai HAM sekular akan semakin mudah meresapi umat Islam jika peranan agama tidak ditonjolkan pada sesuatu 'persekitaran'. Tambahan pula, 'persekitaran' tersebut seringkali meletakkan kedudukan manusia di tahap paling atas dan mempopularkan kejayaan mereka seolah-olah kecemerlangan dalam hidup boleh berlaku tanpa dibantu oleh nilai agama dalam diri manusia. Tarbiyah islamiah dilihat begitu penting bagi menangani permasalahan ini meliputi aspek teori dan amali. Ajaran agama tidak seharusnya ditanamkan hanya secara teori semata-mata tanpa diserlahkan secara amali dalam kehidupan harian. Ia tidak boleh disampaikan hanya melalui pendidikan formal dan tidak formal sahaja, bahkan mesti dibudaya dan diserlahkan dengan kepimpinannya melalui teladan. Kini, nilai HAM sekular agak begitu berjaya di peringkat global melalui projek globalisasi. Ia juga semakin mendapat sokongan secara terbuka dari golongan agama dan pemikir Islam yang cenderung mengiyakan kepelbagaian tuntutannya berbanding tuntutan yang telah ditetapkan oleh agama. Keadaan sedemikian berlaku kerana mereka juga dikatakan turut dipengaruhi oleh 'persekitarannya'. Pengaruh 'persekitaran' yang dimaksudkan termasuklah pergaulan sesama masyarakat yang mengelilingi, sumber bahan bacaan yang diperolehi, kejahilan ilmu dalam memahami, ketaksuban pemikiran yang dimiliki, jaringan sosial yang dilayari di samping kegagalan dalam menghayati ajaran agama yang dianuti. Ini akan menjadikan tuntutan-tuntutan yang diperjuangkan kelak bersifat lebih mementingkan hawa nafsu, logik akal modenisme dan emosi diri sekiranya peranan agama gagal ditempatkan pada kedudukan teratas dalam 'persekitaran' tersebut.

Sikap masyarakat banyak berubah disebabkan oleh faktor 'persekitaran'. Mereka kini banyak terdedah pada 'persekitaran' yang memahami konsep 'kemanusiaan' menurut acuan Hak Asasi Manusia moden berbanding acuan agama. Masyarakat turut terdedah pada persoalan bersifat material dan fizik semata-mata terhadap alam yang diamati, lalu cuba menyelesaikannya dengan kaedah yang sama, tanpa mengambil kira aspek spiritual dan metafizik (Porter 1999: 77). Dalam konteks Islam, Allah s.w.t dengan kudrat dan iradah-Nya telah menciptakan alam bukanlah semata-mata untuk difahami secara material dan fiziknya, malah meliputi spiritual dan metafizik. Manusia merupakan sebahagian daripada alam yang luas ini. Kemudian, manusia sebagai makhluk ciptaan Allah s.w.t dengan ikhtiarnya yang amat terbatas, juga berupaya menghasilkan ciptaan masing-masing (dengan izin Allah s.w.t) pada 'persekitaran' yang didiami. Burung tempua boleh menghasilkan sarangnya yang begitu cantik terletak di pohon yang tinggi untuk didiami manakala lebah pula boleh menghasilkan madu yang baik untuk kesihatan manusia melalui proses yang melibatkan himpunan pelbagai manisan bunga. Manusia pula boleh menghasilkan taman bunga yang cantik, bangunan tinggi yang tersergam indah, kapal terbang yang canggih dan pelbagai kemudahan untuk kegunaan orang ramai. Ini menunjukkan manusia mempunyai pelbagai kelebihan berbanding makhluk lain kerana mereka telah dianugerahkan dengan akal oleh Allah s.w.t untuk menjadi serba boleh dari segi ilmu dan ikhtiarnya dalam menghasilkan pelbagai ciptaan berbanding dengan makhluk lain. Akan tetapi, manusia juga boleh menghasilkan persekitaran yang buruk berbanding makhluk lain. Antaranya, mereka boleh menghasilkan pencemaran alam sekitar, perbuatan jenayah, budaya songsang serta pemikiran yang sekular, liberal dan sebagainya.

Jika melihat kepada pandangan Ibn Khaldun (m. 1406M) sebelum ini, mungkin boleh disimpulkan bahawa 'persekitaran' telah mempengaruhi sikap manusia termasuklah dari segi kepelbagaian tuntutan mereka ke atas alam yang didiami. Namun, jika dianalisis secara pemahaman terhadap ayat-ayat al-Quran seperti dalam surah Yunus (10:12), al-Rum (30:41), alHajj (22:66) dan al-Alaq (96:6-7), telah menunjukkan bahawa manusia begitu banyak melakukan perubahan pada 'persekitaran' alam terutama sekali bersifat kerosakan dan kemungkaran. 'Persekitaran' bukanlah semata-mata merujuk kepada kewujudan zahir secara langsung, malah ia turut melibatkan kewujudan zahir secara tidak langsung seperti yang 
dibawakan oleh proses globalisasi iaitu penggunaan sains dan teknologi maklumat melalui layaran internet. Ini menjadikan skop 'persekitaran' itu semakin luas tanpa sempadan (George 2006: 44-45). Sebagai contoh, masyarakat seluruh dunia yang melayari internet sentiasa terdedah kepada pengaruh 'persekitaran' sama ada positif mahupun negatif yang dibawakan melaluinya termasuklah bagi mereka yang melanggani Facebook, WhatsApp, Email dan sebagainya. Inilah yang merupakan jawapan kepada persoalan bagaimana bawaan Barat moden melalui tuntutan Hak Asasi Manusia boleh mempengaruhi dunia Islam dengan begitu ketara. Globalisasi dalam bidang teknologi maklumat, penyiaran dan komunikasi ke serata dunia dengan membawa nilainya, semakin mempengaruhi masyarakat dunia. Masyarakat Islam kini terdedah kepada pemahaman budaya masyarakat Barat moden yang meminggirkan nilai agama seperti mengamalkan budaya hubungan seks bebas, songsang (gay dan lesbian), hiburan melalaikan, tindakan keganasan dan kekejaman oleh media cetak dan elektronik seperti radio, televisyen dan internet. Ia akhirnya berpotensi mempengaruhi tingkah laku mereka. Keadaan ini menunjukkan pengaruh 'persekitaran' tanpa sempadan amat memainkan peranan besar terhadap keinginan (tuntutan), sikap dan budaya manusia.

Di zaman sekarang, tuntutan-tuntutan atas nama Hak Asasi Manusia banyak bergerak melalui slogan ataupun kata-kata kunci seperti 'kebebasan', 'kesamarataan' dan menghapuskan 'diskriminasi'. Dalam konteks masyarakat Melayu, setiap kata kunci mempunyai makna yang tersirat walaupun ia hanyalah kata-kata ataupun bahasa. 'Bahasa' bukan sahaja memberikan makna, malah ia adalah paparan tingkah laku dan jiwa penuturnya, sekaligus mencerminkan akal budi penuturnya. Setiap ungkapan mempunyai makna tersirat yang perlu difahami secara spiritualnya (Nor Hashimah Jalaluddin 2014: 5 \& 58-59). Jika masyarakat Melayu terlalu menerima segala kata kunci seperti 'kebebasan' dan 'kesamarataan' yang berpaksikan nilai demokrasi Barat atas nama Hak Asasi Manusia, ia sebenarnya satu kejayaan penyerapan nilai sekular melalui projek 'globalisasi' modenisme. Kesan tersebut akhirnya menghapuskan nilai budaya Timur masyarakat tradisi beragama yang sebenarnya berasal daripada nilai Islamiah.

Sejarah menunjukkan bahawa setelah dunia memasuki era moden, nilai Hak Asasi Manusia sekular mula menjelajah ke seluruh dunia termasuklah ke atas masyarakat Timur dan Islam. Kini, ramai masyarakat Islam yang sudah mula berfikiran, berfalsafah dan bersikap di luar batasan adat budaya tradisi masyarakat Timur dan agama. Perihal sedemikian berlaku akibat dorongan hawa nafsu tanpa kawalan dan penyalahgunaan akal yang dimiliki dalam memenuhi segala tuntutan berbanding menghayati ajaran agama yang dianuti. Sarjana Melayu seperti Za'ba (m. 1973M) menjelaskan, tuntutan pada budaya dan akhlak masyarakat Barat moden tidak boleh diikut sewenang-wenangnya oleh masyarakat Islam. Ini kerana, paksi bagi ukuran perbuatan baik dan buruk masyarakat Barat moden bukanlah agama (Za'ba 2009: 97). Bermula daripada kekurangan penghayatan beragama yang dimiliki oleh umat Islam, sebaliknya didedahkan pula secara berlebih-lebihan gambaran budaya Barat moden dengan mudah melalui media cetak dan elektronik termasuklah radio, televisyen, internet dan sebagainya, maka tidak menjadi satu kejutan bahawa budaya Barat moden begitu mudah meresapi masyarakat Islam berbanding budaya Timur pada hari ini.

\section{Kehilangan Sifat Syukur Melahirkan Tuntutan Keterlaluan}

Tuntutan Hak Asasi Manusia pada dasar permulaannya adalah memperjuangkan 'kesamarataan' dari sudut ekonomi sebagai keperluan asas kehidupan. Namun, kecenderungan mereka untuk menuntut lebih daripada sekadar keperluan hidup, adalah disebabkan kehidupan mereka semakin berada di zon selesa, sekaligus cenderung pula untuk menuntut lebih daripada itu. Ini ditambah pula manusia itu sendiri kecenderungannya begitu mudah dipengaruhi oleh suasana 'persekitaran' sama ada baik mahupun buruk. Jika diri mereka tidak dididik, dilatih dan didedahkan melalui ruangan ikhtiar yang baik, maka sikap jahat akan menguasai dirinya (Za'ba 2009: 103-104). Sifat syukur merupakan satu kebaikan yang perlu ada dalam diri manusia. 
Kehilangan sifat syukur boleh menyebabkan manusia mengalami penyakit tamak dan lalai sepertimana yang disebutkan oleh Ibn Khaldun:

\begin{abstract}
Suatu yang harus diketahui ialah perbezaan-perbezaan keadaan di antara penduduk adalah diakibatkan oleh perbezaan cara-cara mereka mendapatkan nafkah hidup. Organisasi sosial membolehkan mereka saling bantu-membantu ke arah itu dan ianya bermula dengan keperluan hidup secara sederhana, sebelum mereka beroleh kesenangan dan kemewahan. . . Ia disusuli oleh peningkatan menikmati kemewahan dan keselesaan, lalu menjadikan kepada pembentukan hidup mewah yang melampaui batas (Ibn Khaldun 2000: 81-82).
\end{abstract}

Isu 'pembangunan' dan 'kemajuan' material seringkali dikaitkan dalam ruangan ekonomi. Ia memberikan reaksi terhadap hubungan sosial termasuklah tentang perubahan gaya hidup ataupun sikap manusia (Rabi` 1967: 42-43 \& 159-160). Perubahan sikap manusia boleh dikaitkan dengan perubahan 'persekitaran' yang mengelilingi mereka. Manusia yang sentiasa terdedah pada budaya tradisional yang penuh dengan amalan tradisi beragama, didapati sikapnya adalah lebih bersyukur dengan apa yang ada dan tidak akan memikirkan keinginan atau tuntutan yang keterlaluan di luar budaya hidup mereka. Berbeza bagi mereka yang dikelilingi dengan suasana kemewahan, sikapnya adalah lebih mudah menjadi tidak bersyukur dengan apa yang ada, malah sentiasa menginginkan lebih daripada itu sehingga melanggari norma kehidupan manusia dan peraturan agama (Ibn Khaldun 1981: 46-47). 'Persekitaran' yang mengelilingi manusia, secara langsungnya mempengaruhi tuntutan manusia sama ada menuju kepada keperluan hidup atau kepentingan diri yang dikelilingi hawa nafsu.

Bawaan HAM Barat moden yang akhirnya telah mempengaruhi pelbagai lapisan masyarakat termasuklah umat Islam, telah menyebabkan nilai agama dan budaya Timur semakin dipinggirkan. Sebabnya, HAM yang diguna pakai pada hari ini adalah HAM sekular di bawah piawaian antarabangsa atas nama 'demokrasi' Barat (Azril Mohd Amin 2013: 1). Dalam Islam, sebarang tuntutan yang dianggap sebagai keperluan bagi umat manusia, adalah wajib diikatkan dengan nilai agama. Kewajipan berpaksikan ajaran Islam terutamanya al-Quran dan al-Sunnah di dalam mencapai sebarang tuntutan, bertujuan memastikan setiap tuntutan, tingkah laku dan hala tuju umat Islam sentiasa tertakluk di bawah syariat ('Abd al-Rahim 2014: 48-49). Umat Islam tidak boleh meniru Hak Asasi Manusia acuan Barat kerana ia terlalu jelas bergantung kepada logik akal modenisme dan hawa nafsu hedonisme. Penerimaan Hak Asasi Manusia acuan Barat di kalangan umat Islam, sebenarnya menunjukkan bahawa mereka telah dipengaruhi secara besar-besaran oleh 'persekitaran' tanpa sempadan, yang turut disumbangkan oleh kejahilan mereka dalam memahami nilai agama. Paling tidak boleh dinafikan, penerimaan tersebut turut disumbangkan oleh kegagalan mereka untuk memahami implikasi negatif daripada pandangan alam (worldview) moden yang tidak berasaskan prinsip dan nilai agama terhadap pemikiran dan kehidupan manusia.

Keutuhan sesebuah masyarakat hanya boleh dipertahankan melalui pembudayaan nilai agama iaitu mentaati peraturan-peraturan (syariah) yang telah ditetapkan oleh Allah s.w.t berdasarkan penguasaan dan penghayatan ilmu agama serta penggunaan akal secara berhikmah. Ia mampu menangani tuntutan-tuntutan dan sikap melampaui batas umat manusia yang tidak pernah bersyukur dengan apa yang dimiliki (Rabi`1967: 169). Perkara inilah yang sentiasa ditekankan oleh para ahli falsafah Islam sebelum kedatangan zaman moden lagi seperti al-Farabi (m. 950M), Ibn Miskawayh (m. 1030M) dan Ibn Rushd (m. 1198M) yang berpendapat, manusia sentiasa perlu bergantung kepada ajaran Allah s.w.t dalam usaha untuk mengenali diri mereka sendiri sebagai makhluk yang boleh berfikir dan berkewajipan untuk taat kepada-Nya. Manusia dikurniakan akal bukan semata-mata untuk memahami tentang diri mereka sahaja, bahkan yang paling utama adalah untuk memahami dan memikirkan tentang kewujudan hubungan antara mereka dengan Pencipta iaitu Allah s.w.t (Ibn Miskawayh 1901: 10; Ibn Rushd 1986: 27; al-Farabi 1995: 83-90). 
Ini berbeza sekali dengan pandangan-pandangan ahli falsafah di zaman moden terutamanya dari Barat, yang terlalu mengagung-agungkan Hak Asasi Manusia sekular sebagaimana yang dibawakan oleh Karl Marx (m. 1883M) dan rakannya Friedrich Engels (m. 1895M). Mereka berdua cukup dikenali sebagai ahli falsafah Barat moden beraliran sosialisme, tetapi akhirnya menuju kepada ateisme. Bagi mereka, teras kehidupan manusia adalah ekonomi, bukannya agama. Agama hanyalah khayalan manusia semata-mata yang boleh menghalang mereka daripada mencapai 'pembangunan'. Manusia diberikan 'kebebasan' untuk membangunkan diri mereka dalam apa cara sekalipun, dan agama tidak ada hak untuk menentukan peraturan manusia (Marx 1964: 107-108). 'Kebebasan' perbuatan manusia mestilah bernaung di bawah acuan falsafah Dialektik Materialisme dan politik Komunisme, yang mementingkan 'kesamarataan' serta mengkehendaki mereka agar sentiasa menjauhkan diri daripada agama. Agama dianggap tidak berperanan untuk membantu manusia dalam membangunkan ekonomi negara. 'Humanisme' pula mestilah difahami sebagai manusia bebas tanpa agama, dan memandang ekonomi sebagai teras pembangunan (Marx 1964a: 243-244; Marx \& Engels 1969: 62 \& 68). Inilah yang dikaitkan dengan fahaman ateisme yang menafikan Tuhan dalam memandang alam (Qutb 1988: 605). Apa yang dapat disimpulkan, konsep 'kebebasan' pada tuntutan dan tingkah laku manusia yang diteorikan oleh ahli falsafah moden tersebut, telah bermula dari aspek membangunkan ekonomi manusia dan negara. Namun, mereka akhirnya menuju kepada teori kritikan terhadap agama sehingga membawa kepada nilai ateisme. Ia merupakan kesan daripada kefahaman yang salah tentang konsep 'kebebasan' manusia sehingga membawa kepada unsur modenisme, sekularisme dan ateisme. Sejarah falsafah tersebut juga menunjukkan, permulaan bagi 'persekitaran' yang tidak menonjolkan peranan agama begitu ketara berlaku di zaman moden khususnya di Barat. Isu ekonomi diperbesarkan dan dimanipulasi demi menghilangkan suasana budaya amalan masyarakat beragama ketika itu, sekaligus membentuk 'persekitaran' Barat moden sekular.

Dengan keadaan 'persekitaran' tanpa sempadan melalui proses globalisasi sebagaimana yang berlaku pada hari ini, maka umat Islam semakin mudah terdedah kepada mana-mana budaya yang seringkali dihadapinya secara media cetak mahupun elektronik terutama sekali dari dunia Barat yang begitu terkehadapan di dalam menyalurkan sebarang maklumat ke seluruh dunia. Ini ditambah pula dengan penyediaan prasarana yang begitu baik dari sudut sains dan teknologi maklumat di kebanyakan negara Islam, sekaligus mempertingkatkan jumlah keupayaan pengaruh 'persekitaran' tanpa sempadan. Oleh itu, 'persekitaran' sedemikian mempunyai dua potensi iaitu pendedahan kepada pengaruh yang baik mahupun buruk. Akan tetapi, apabila 'persekitaran' berpaksikan nilai agama dan budaya Timur sudah tidak lagi ditonjolkan dalam dunia tanpa sempadan berbanding 'persekitaran' berpaksikan nilai akal rasional yang mendewakan akal manusia dan budaya Barat moden, ia akhirnya akan memberi ruang kepada umat Islam untuk terpengaruh dengan mana-mana persekitaran yang lebih dominan dan kerap dihadapinya. Inilah yang berlaku dalam konteks masa kini apabila slogan Hak Asasi Manusia versi Barat moden semakin mempengaruhi dunia Islam. Istilah 'kebebasan' telah diglobalkan penggunaannya dari aspek ekonomi menuju kepada aspek 'membebaskan' diri daripada ikatan agama. Kesan daripada itu telah menjadikan Hak Asasi Manusia tersebut semakin kuat pengaruhnya sebagai 'agama' baru bagi menggantikan ajaran tradisi beragama. Berdasarkan 'persekitaran' yang dipenuhi dengan kecanggihan peralatan sains dan teknologi maklumat moden yang sering memaparkan budaya Barat di samping 'persekitaran' tersebut kurang pula didedahkan dengan budaya beragama (persekitaran yang jahil tentang ilmu dan penghayatan agama), maka ia secara tidak langsung boleh mempengaruhi umat Islam ke arah keburukan berbanding kebaikan. Dalam Islam, tiada kebenaran bagi mereka untuk bertindak 'bebas' melampaui batasan agama termasuklah dalam membuat tuntutan atas nama Hak Asasi Manusia. Sebabnya, setiap peraturan yang disediakan oleh agama adalah untuk kebaikan sejagat. Manusia tetap terikat dengan peraturan sepanjang hidup mereka khususnya peraturan yang dibawakan oleh agama demi kesejahteraan untuk semua pihak. 


\section{References}

Al-Quran.

'Abd al-Rahim, Muddathir. 2014. Hak asasi kemanusiaan dalam tradisi Islam. Transl. Kuala Lumpur: Allied Coordinating Committee of Islamic NGOs.

Azril Mohd Amin. 2013. UDHR and the position of Islam in Malaysia's Federal Constitution. Kertas kerja Seminar Mendaulatkan Islam Agama Negara. Anjuran Pertubuhan Muafakat Sejahtera Masyarakat Malaysia (MUAFAKAT) dan Jabatan Kemajuan Islam Malaysia (JAKIM). Kuala Lumpur, 5 January.

al-Farabi, Abu Nasr. 1995. Kitab tahsil al-sa adah. Beirut: Dar wa Maktabat al-Hilal.

Feuerbach, L. 1957. The essence of Christianity. Transl. G. Eliot. New York: Harper Torchbooks.

George, S.E. 2006. Religion and technology in the 21st Century: Faith in the e-world. Hershey: Information Science Publishing.

Ibn Khaldun, `Abd al-Rahman. 1981. Muqaddimah Ibn Khaldun. Beirut: Dar al-Fikr.

Ibn Khaldun, `Abd al-Rahman. 2000. Mukadimah Ibn Khaldun. Transl. Kuala Lumpur: Dewan Bahasa dan Pustaka.

Ibn Manzur. 1996. Lisan al-'Arab. Jil. 3. Beirut: Dar Ihya' al-Turath al-'Araby.

Ibn Miskawayh, Abu `Ali Ahmad. 1901. Al-fawz al-asghar. Beirut: t.pt.

Ibn Rushd. 1986. Kitab fasl al-maqal wa waqrir ma bayn al-shari ah wa al-hikmah min al-ittisal. Sunt. Albayr Nasri Nadir. Beirut: Dar al-Mashriq.

Kristeller, P.O. 1972. Renaissance concepts of man. New York: Harper \& Row Publishers.

Lonergan, B.J.F. 1973. Philosophy of God and Theology. London: Darton, Longman \& Todd.

Marx, K. 1964. Pre-capitalist socities. Dlm. T.B. Bottomore \& M. Rubel (pnyt.). Selected writings in Sociology \& Social Philosophy, hlm. 103-124. New York: McGraw-Hill Book Company.

Marx, K. 1964a. Future society. Dlm. T.B. Bottomore \& M. Rubel (pnyt.). Selected writings in Sociology \& Social Philosophy, hlm. 241-258. New York: McGraw-Hill Book Company.

Marx, K. \& Engels, F. 1969. Manifesto of the Communist Party. Dlm. L.S. Feuer (pnyt.). Basic Writings on Politics and Philosophy, hlm. 43-82. Ed. Ke-2. Great Britain: Collins.

Mcllhenny, C., McIlhenny, D. \& York, F. 1993. When the wicked seize a city. Louisiana: Huntington House Publishers.

Nasharudin Mat Isa. 2014. Tuntutan hak asasi manusia dan ancamannya terhadap Islam. Kajang: Yayasan Nassar.

Noresah Baharom. 2007. Kamus Dewan. Ed. ke-4. Kuala Lumpur: Dewan Bahasa dan Pustaka.

Nor Hashimah Jalaluddin. 2014. Semantik dan akal budi Melayu. Bangi: Penerbit Universiti Kebangsaan Malaysia.

Porter, J. 1999. From natural law to human rights: or, Why rights talk matters. Journal of Law and Religion 14: 77-96.

Qutb, Muhammad. 1988. Madhahib fikriyyah mu asirah. Ed. Ke-4. Cairo: Dar al-Shuruq.

Rabi', Muhammad Mahmoud. 1967. The political theory of Ibn Khaldun. Leiden: E.J. Brill.

Za'ba. 1980. Falsafah takdir. Kuala Lumpur: Dewan Bahasa dan Pustaka.

Za'ba. 2009. Perangai bergantung pada diri sendiri. Kuala Lumpur: Dewan Bahasa dan Pustaka. 